Yuri R. Achokh

\title{
Improvement of the economic efficiency of protective forest plantations in the agricultural sector of the Russian Federation
}

\author{
KEYWORDS \\ protective forest plantations; \\ forest belts; \\ agro-industrial complex; \\ agrolandscapes; \\ agricultural land; \\ productivity; \\ land reclamation; \\ economic efficiency
}

FOR CITATION

\section{ABSTRACT}

The condition and efficiency of land use is a determining factor in ensuring the balanced development of the agro-industrial complex, nature management, as well as environmental and food security of the country. The priority areas for ensuring sustainable development of the agro-industrial complex include the fight against deforestation; rational use of vulnerable ecosystems with desertification and drought; creation of compensating sites with forest vegetation; greening of land use through the new optimal planning of agrolandscapes.

The methodological and theoretical basis of the study is the studies and works of leading domestic and foreign scientists, materials of scientific and practical conferences of various levels in the field of protective afforestation and agroforestry. The information base for the study is the regulatory legal acts (the Forest Code, a number of federal laws, orders of the Federal Forestry Agency, etc.) that govern issues on the problem under study.

As a result of the research, an assessment of the state of protective forest plantations in the Russian Federation is given, potential advantages of using protective forest plantations in the agricultural sector are identified, the role of the state in solving environmental and social problems on this issue is determined.

State measures are proposed to solve the problems of increasing the efficiency of the use of protective forest plantations in the agro-industrial complex, including the transfer of protective forest plantations to the ownership of agricultural enterprises and farms with mandatory responsibility for their proper maintenance and preservation.

Achokh, Yu. R. (2020). Improvement of the economic efficiency of protective forest plantations in the agricultural sector of the Russian Federation. Economic consultant, 29 (1), 39-48. doi: 10.46224/ ecoc.2020.1.4 


\section{INTRODUCTION}

$\mathrm{T}$ he priority areas for ensuring sustainable development of the agro-industrial complex at the global level include the fight against deforestation; rational use of vulnerable ecosystems with desertification and drought; creation of compensating sites with forest vegetation; greening of land use through the new optimal planning of agrolandscapes.

The condition and efficiency of land use is a determining factor in ensuring the balanced development of the agro-industrial complex, nature management, as well as environmental and food security of the country.

It has been established by scientists that one of the main factors in reducing the productivity of land resources in the agro-industrial complex is the degradation of agrolandscapes due to the prolonged use of insufficiently ecological farming systems, the violation of the optimal structural and functional organization of the territory, the balance of its main stabilizing components, leading to a decrease in the erosion resistance of agrolandscapes, and the deterioration of their ecological state [1]. The ecological state of agrolandscapes in the state is characterized by a large-scale threatening manifestation of erosion processes that negatively affect the ecological state of the environment, reduce the productivity of land resources, and, consequently, crop yields. Many years of experience in agricultural production show that the use of only agrotechnical measures, even the most modern, does not ensure the stability of agricultural landscapes [2]. Therefore, the land reclamation measures should be used to stop the manifestation of degradation processes. The implementation of forest reclamation in combination with agrotechnical measures in the practice of agricultural production should be a strategic direction of agrolandscape management.

The aim of the study is to develop theoretical and methodological foundations of the economic efficiency of use and directions for the development of protective forest plantations in the agricultural sector in the context of the requirements of current legislation and environmental realities.

\section{MATERIALS AND METHODS}

The research materials are the fundamental provisions of the general economic theory, the works of domestic and foreign scientists in the field of economics and national economy management, nature management (forest management) in the agricultural sector, the legal acts on the issue under study (Federal Law of January 10, 1996 No. 4-FZ "On Land Reclamation", Federal Law of December 27, 2018 No. 538-FZ "On Amendment of the Forest Code of the Russian Federation" and individual legal acts of the Russian Federation in terms of improvement of the legal regulation of the relations concerned with ensuring the conservation of forests on the lands of the forest fund and the lands of other categories, the FFA Order of December 5, 2011 No. 509 "On Approval of the Rules of the Use of Forests for Agriculture" and others). 


\section{RESULTS}

Nowadays, the current state of protective forest plantations and their systems for various purposes does not ensure the protection of agricultural territories and the stable functioning of agricultural landscapes. Insufficient agricultural afforestation and protection, excessive plowing of protective forest plantations, and a low share of conditionally stable lands in the structure of agricultural lands - hayfields, pastures, perennial plantings - do not ensure the ecological sustainability of agrolandscapes.

Over the past decade, hundreds and even thousands of kilometers of protective forest plantations have been eradicated recklessly and with impunity. This leads to the massive devastation of agricultural land. Due to the lack of forest-protective activities, protection from pests, diseases, they are in an unsatisfactory sanitary condition, willfully cut down, and dying from fires. Despite the discrepancy in numbers, most scientists agree that on average 10\% of the yield depends on the state of the protective forest plantation, correctness of its creation and grooming [3].

The level of forest coverage, in particular, the field protection of modern agrolandscapes remains low; no work is being done to create and restore the forest belts, which leads to the development of a number of negative processes, both in the use of land and in the management system. The importance of protective forest plantations in productivity improvement of the agroindustrial complex is noted in the writings of both domestic and foreign scientists. According to their studies, the growth potential of crop yields in the system of protective forest plantations can be up to $20 \%$, pasture productivity can be up to $25 \%$, dairy production can be up to $12 \%$, etc. [4]. With a difference in forest cover of $1.5 \%$, the differences in yield for winter wheat are on average $29.8 \%$, barley $-37.1 \%$, oats $-27.2 \%$ [5]. The yield increase for every $0.5 \%$ of arable land afforestation is from 0.75 to $3.5 \%$ [6].

Recently, there have been trends in climate warming and an increase in extreme weather events. In particular, climate analysis shows an increase in the frequency of hot years over the past decades, and this trend is expected to remain. Therefore, the correct placement of the system of protective forest plantations can create the appropriate microclimatic conditions and reduce heat stress for crops, animals and people.

Protective forest plantations are of particular importance for the development of the agricultural sector. They protect agricultural land from flooding, water and wind erosion of soils, contribute to the intensification of humification processes, regulate the water-air regime, and positively affect climatic conditions. They perform environmental-forming, climate-forming and water-regulating functions, positively affect the productivity and economic efficiency of agricultural land use. Their optimal combination in the landscapes of various natural and economic zones affects the location and specialization of agricultural production [7].

Protective forest plantations are zoned. The small contour of the worst lands, their dispersion between forests, swamps and lakes requires a special approach to the agricultural system. 
Drainage of wetlands and waterlogged lands, radical improvement of meadows and pastures, land management of farms, crop rotation, soil cultivation, management of its water-air regime must be carried out taking into account afforestation of the territory and the influence of protective forest plantations on agricultural production conditions.

The expansion of the area of protective forest plantations, the improvement of their natural composition, and the rational system of forestry make it possible to increase the growth of commercial timber in the future and provide it with all household needs. A special type of natural resource is water, which is used in all sectors of material production, as well as a food product. It finds its application to provide water to industry and agriculture, rural and urban settlements [8].

According to Article 7 of the Federal Law "On Land Reclamation" dated October 1, 1996 No. 4-FZ, the agroforestry of lands is a complex of land reclamation measures that provide radical improvement of lands through the implementation of soil-protective, water-regulating and other properties of protective forest plantations [9].

Agroforestry is a holistic system of forestry activities aimed at improving the soil and hydrological conditions of a particular region, ensuring a higher level of environmental and economic efficiency of agriculture and increasing production in the food and processing industries of the agro-industrial complex by improving the quality of products.

Agroforestry of land includes the following types:

- anti-erosive protection - protection of land from erosion by creating forest stands on ravines, gullies, sands, river banks, and other territories;

- field protection - protection of land from the effects of adverse events by creating protective forest plantations along the borders of agricultural land;

- pasture protection - prevention of land degradation of pastures by creating protective forest plantations [10].

In accordance with Article 30 of the Federal Law "On Land Reclamation", the construction of objects on reclaimed (being reclaimed) lands and other activities not intended for land reclamation should not impair the water, air and nutrient regimes of soils on reclaimed lands, as well as hinder the operation of reclamation systems, separately located hydraulic structures and protective forest plantations.

However, the uncertainty of the legal position of protective forest plantations, the procedure for their accounting and maintenance rules, ultimately made them ownerless, degraded, moreover, they became the sources of fire danger. Their reproduction was specially funded from the federal budget. On January 1, 2020, amendments to the Federal Law "On Land Reclamation" entered into force. The draft law provides for the obligation of the land rights holders to maintain and preserve ameliorative protective forest plantations. Moreover, in cases where the plantations are located in areas owned by the state or municipal property and are not transferred for use to thirdparty organizations, these responsibilities are assigned to the authorities.

According to Article 29 of the Federal Law "On Land Reclamation", citizens (individuals) and legal entities that operate land reclamation systems, separately located hydraulic structures 
and protective forest plantations are required to keep these facilities in good condition and take measures to prevent damage to them.

The Federal Law "On Land Reclamation" develops the legal framework for agroforestry as the most important area of agricultural land reclamation, which is of particular importance for steppe and forest-steppe regions where there is a lack of moisture in the soil, and protection of field and pasture lands from erosion in all agricultural zones of the country.

Protective forest plantations are man-made forest belts. Their goal is to protect various objects from adverse natural and anthropogenic factors [11]. In the case of farmland, forest belts help to combat drought, soil erosion from water and wind. They are planted or sown mainly in the steppe, forest-steppe and semi-desert regions.

Protective afforestation is an integral part of the scientific system of agriculture, used to prevent the negative impact of natural and anthropogenic factors on field lands [12]. Such a system should be considered not only as a factor in a certain increase in soil fertility, but in a broader sense, as a factor in scientifically sound land management and the organization of optimal agricultural production and other activities. Under the influence of protective forest plantations, the risk of death of winter crops is reduced. Protective forest plantations have the ability to prevent the transformation of fertile lands into badlands in erosion-hazardous places (restraining the formation and growth of ravines).

According to the latest report of the Ministry of Agriculture of the Russian Federation "On the State and Use of Agricultural Land in 2017", out of 10,485.44 thousand ha of arable land surveyed for the presence of wind and water erosion, wind erosion was detected on an area of $1,424.17$ thousand ha (13.6\% of the total area under study), water - on the area of $1,847.17$ thousand ha (17.6\%) [13]. The area of protective forest plantations in the Russian Federation has almost halved: 2.74 million hectares out of 5.2 million hectares are currently preserved. About $60 \%$ of all protective stands exceeded the permissible critical age [14].

Some regions allocated funds for the maintenance of protective forest plantations from regional budgets (for example, the Krasnodar Territory), partially the federal center co-financed these expenses in support of general regional land reclamation programs. As follows from the National Report on the Progress and Results of the Implementation in 2018 of the State Program for the Development of Agriculture and the Regulation of Agricultural Products, Raw Materials and Food Markets for 2013-2020, agroforestry measures were carried out only on an area of 119.1 thousand ha [15].

The Ministry of Agriculture of the Russian Federation has developed a program for involvement of agricultural lands in the turnover and development of the reclamation complex. Agroforestry should become part of this program. The new law, which comes into force on July 1,2020 , creates a legal framework for this.

The economic efficiency of the use of protective forest plantations in the agricultural sector should be based on the magnitude of the effect of the influence of the social and environmental functions of the protective forest plantations on increasing the efficiency of agricultural production and productive labor in agriculture. The problem of determining 
the economic effect of the use of the environmental and social functions of protective forest plantations is quite complex, because, for example, soil protection, water regulation, and recreational functions do not have a material form, so it is difficult to make a quantitative measurement. However, the ecological function of protective forest plantations is important in the agricultural sector. The source of the effect is soil-protective plantations - field-protective forest plantations, shrubs along river banks, etc., which are used to protect agricultural lands from erosion and contribute to improving soil fertility, protecting plants from adverse climatic factors. The great value of protective forest plantations is especially evident in dry years, during floods and intense snowmelt. Special studies show that due to protective forest plantations, grain yield increases by $3-5 \mathrm{~kg} / \mathrm{ha}$, and the cost of crop production decreases. Each hectare of protective forest plantations protects 20-30 hectares of arable land, and the land allocated for the creation of protective forest plantations is offset by an increase in additional agricultural production [16].

Based on the economic assessment of the use of protective forest plantations in the agricultural sector, the opportunities are created to reflect their value as part of the national wealth of the state, maintain the state regional natural resource cadastre, justify the effectiveness of environmental protection measures, assess the amount of losses caused to nature by natural phenomena and unsustainable ways of exploiting natural resources, improvement of the economic regulation methods by the processes of environmental management.

\section{DISCUSSION}

Thus, the most important problem of the agro-industrial complex is to increase the economic exploitation efficiency of both new and existing production assets. In this regard, it is important to find out how the funds allocated by the state and agricultural enterprises for protective afforestation are used.

The evaluation of the actual efficiency of capital investments in protective afforestation is not limited to the volume of additional production and the size of the annual net income. As a result of obtaining additional products from the reclamation effect of protective forest plantations and an increase in this volume of annual net income, the cost of the main crop production decreases [17].

The economic efficiency of protective forest plantations is estimated as the effectiveness of auxiliary (for creating forest strips) capital investments in the agricultural sector, aimed at increasing labor productivity, increasing crop production, reducing its cost and increasing income. This is the differential rent received from additional investments to increase agricultural land productivity. It is based on the protection by protective forest plantations of part of the crop from adverse conditions, and in areas of wind erosion and the protection of the soil from blowing.

The creation of protective forest plantations is associated with additional costs: the main ones are for the creation of stands and the return is for the collection, completion, transportation 
of additional products. At the same time, additional costs associated with protective forest plantations are 2-3 times less than the cost of crop growth. In this regard, in fields protected by forest belts, the cost of production is lower, and the profit and profitability of crop production are much higher [18].

One of the most important indicators of the economic efficiency of capital investments in protective forest plantations in the agricultural sector is the payback period. The smaller it is, the higher the investment efficiency. The payback period for the creation of protective forest plantations in the agricultural sector depends mainly on the main species and soil and climatic conditions that determine the height of the stands. The payback period for the creation of protective forest plantations from poplar on ordinary chernozems is five years, and ten years for oak protective forest plantations. Since that time, protective forest plantations begin to make a profit, it is the higher, the older the stands.

In addition to the payback period, the economic efficiency of the use of protective forest plantations in the agricultural sector can be characterized by such indicators as the volume of gross output per 1 thousand rubles of fixed assets, the reduction of the production costs and the profits from protective forest plantations and the like. The profit from protective forest plantations or agroforestry income can be calculated per 1 ha of protective forest plantations and per 100 ha of arable land protected by them. The calculation per 1 ha of forest belts can be done for one year, for a number of years, and for the whole life of plantations [19].

The volume of additional products from the use of protective forest plantations in the agricultural sector is determined by multiplying the area of the main crops under the protection of forest stands by the corresponding increase in yield.

A monetary assessment of the additional yield of grain and industrial crops (sunflower, sugar beets, etc.) is carried out at the current zonal purchasing prices, fodder crops (silage, herbs, root crops, melons, hay, etc.), then the result is transferred to feed units and evaluated at the price set for oats [20].

All data for determining the cost of manufacturing additional products is taken according to the accounting report, estimates or technological maps of crop cultivation.

The costs (capital investments) for the creation of protective forest plantations in the agricultural sector are calculated at the actual costs [21].

Thus, the economic efficiency of protective forest plantations in the agricultural sector is composed of:

- reduction of the damage caused by dust storms;

- crop increases due to agroclimatic effects of protective forest plantations;

- beneficial effects on the environment, fauna, labor productivity, livestock products, aesthetic and landscape improvement of the territory;

- reduction of agricultural land and a decrease in the volume of production due to the withdrawal of part of the field areas under protective forest plantations;

- the costs of the creation and growing of protective forest plantations [22]. 


\section{CONCLUSION}

Based on the above characteristics, it can be reasonably argued that it is impossible to achieve stable crop yields without the use of protective forest plantations in the agricultural sector. Implementation of agroforestry measures in accordance with natural and economic conditions favorably affects the indicators of increasing the environmental and economic efficiency of crop production.

The efficiency of the use of protective forest plantations in the agricultural sector at the state level can be improved through the implementation of an indicative list of measures:

1. The implementation of a package of measures to create protective forest plantations at the regional level.

2. The integrated accounting of protective forest plantations, including forest shelter belts.

3. The transfer of protective forest plantations for permanent use to forestry enterprises of the relevant departments, and in some specific cases to the ownership of agricultural enterprises and farms with mandatory responsibility for their proper maintenance and preservation.

\section{REFERENCES}

1. Erusalimskiy, V.I., \& Rozhkov, V.A. (2017). The Multifunctional Role of Protective Forest Plantations. Bulletin of the Soil Institute named after V.V. Dokuchaev, 88, 121-137.

2. Gubaidullina, E.D., Markabaeva, A.A., \& Timeryanov, A.Sh. (2017). Ecological Significance of Protective Forest Plantations. In Actual Problems and Prospects for the Development of Geodesy, Land Management and Real Estate Cadastre in a Market Economy: Materials of Scientific-Practical Conference, Omsk, November 24, 2016 (pp. 41-43). Omsk: OmGAU.

3. Zheldak, V.I. (2018). Protective Forest Plantations in the System of Concepts of Forestry. In Agroecology, Land Reclamation and Protective Afforestation: Materials of International Scientific-Practical Conference, Volgograd, October 18-20. 2018 (pp. 6571). Volgograd: FSC Agroecology RAS.

4. Poluektov, E.V., \& Balakai, G.T. (2018). Influence of Protective Forest Belts on Crop Productivity. In Ecological Problems of the Development of Agrolandscapes and Ways to Increase Their Productivity: Proceedings of the International Scientific Conference, Krasnodar, March 27-29, 2018 (pp. 504-507). Krasnodar: KubSAU.

5. Savinova, I.A. (2017). The Role of Protective Forest Plantations on Agricultural Lands. Sustainable Development of Science and Education, 3, 127-130.

6. Okisheva, O.A. (2018). The Role of Protective Forest Stands on Arable Land. In Priorities of World Science: Experiment and Scientific Discussion: Proceedings of the International ScientificPractical Conference, Kemerovo, October 22, 2018 (pp. 135-137). Kemerovo: ZSNTS. 
7. Moreno, G., Aviron, S., \& Berg, S. (2018). Agroforestry Systems of High Nature and Cultural Value: Provision of Commercial Goods and Other Ecosystem Services. Agroforestry Systems, 92, 877-891.

8. Balakai, N.I. (2016). Functional Purpose of Protective Forest Stands, Their Location and Design. Ways to Improve the Efficiency of Irrigated Agriculture, 2 (62), 63-69.

9. Collection of Legislation of the Russian Federation 1996, No. 3, Item 142.

10. Dzhirgalova, E.A., Kaminov, Yu.B., \& Batyrov, V.A. (2016). Agroforestry: Textbook. Elista: KalmSU. (p. 87).

11.Elevitch, C.R., Mazaroli, D.N., \& Ragone, D. (2018). Agroforestry Standards for Regenerative Agriculture. Sustainability, 10 (9). Retrieved March 4, 2020. doi: 10.3390/ su10093337

12. Vishnyakov, N.V., \& Zimovets, P.A. (2017). The Role of Protective Forest Plantations in Reclamation and Anti-Erosion Measures. In Anthropogenic Transformation of Geospace: History and Modernity: Proceedings of the IV International Scientific-Practical Conference, Volgograd, May 15-19, 2017 (pp. 170-173). Volgograd: VolSU.

13. The Ministry of Agriculture of the Russian Federation. (n.d.). Retrieved February 25, 2020, from http://mcx.ru (reference date: 25.02.2020).

14. Ushakov, R.M., \& Razgeldeev, N.T. (2019). Forestation and Protective Forest Plantations as a Way of Counteracting Soil Erosion: Legislation, Environmental and Legal Doctrine, Practice. In Legal Institutions and Methods for Ensuring Environmental and Natural Resource Safety in Russia, the CIS and European Countries Union: Legislation, Social and Environmental Efficiency: Proceedings of the VI International Scientific-Practical Conference, Saratov, October 11, 2019 (pp. 162-167). Saratov: Saratovskiy istochnik.

15. Petelko, A.I. (2019). Soil-Improving and Soil-Forming Role of Anti-Erosion Protective Forest Stands. In Agroecological Problems of Soil Science and Agriculture: Proceedings of International Scientific-Practical Conference, Kursk, April 24-25, 2019 (pp. 290-294). Kursk: Kursk FANTS.

16. Grosheva, G.V., Sakharova, E.S., \& Nedikova, E.V. (2018). Protective Forest Plantations and Their Impact on the Territory. In Innovative Technologies and Technical Means for the Agro-Industrial Complex: Proceedings of International Scientific-Practical Conference, Voronezh, November 14-16, 2018 (pp. 80-83). Voronezh: VGAU.

17.Pirov, B.N. (2017). Assessment of Protective Forest Stands. In Scientific Potential of the Modern State: Proceedings of International Scientific-Practical Conference, Yekaterinburg, December 19, 2017 (pp. 101-103). Saratov: Academy of Business.

18. Pankratova, N.N., Alekseenko, A.Yu., \& Gul, L.P. (2016). Methodology for Assessing the Economic Efficiency of Forest Reproduction Measures: Textbook. Khabarovsk: DalNIIILH, 2016. (p. 48).

19. Khaertdinov, N.Z., Minnikhanov, A.R., \& Gibadullin, N.F. (2016). Protective Forest Plantations and Soil Fertility. In Preservation of Soil Fertility and Energy-Saving Technologies for Crop Production: Proceedings of All-Russian Scientific-Practical 
Conference, Ufa, March 24-26, 2016 (pp. 104-108). Ufa: BGAU.

20. Ivonin, V.M. (2018). Sustainable Development of Agriculture and Forest Reclamation. Scientific Journal of the Russian Research Institute of Land Reclamation, 1 (29), 122-141.

21.Zotova, K.Yu., \& Nedikova, Ye.V. (2015). Creation of a System of Protective Forest Stands - One of the Methods for Improving the Environment. Economics and Ecology of Territorial Entities, 1, 19-24.

22. Kulik, K.N. (2018). Protective Forest Plantations - the Basis of the Ecological Framework of Agricultural Territories. Bulletin of the Russian Agricultural Science, 1, 18-21.

\section{INFORMATION ABOUT THE AUTHOR}

1. Yuri R. Achokh (Russia, Krasnodar) - Postgraduate student. Kuban State Agrarian University. E-mail: a4ox@mail.ru 